\title{
AUDIT JUDGMENT WITH EMOTIONAL INTELLIGENCE AS MODERATION VARIABLE IN BPKP BALI
}

\author{
Ni Putu Shinta Dewi ${ }^{1)^{*}}$, Ni Komang Kris Muliartini ${ }^{2}$, Ni Wayan Rustiarini ${ }^{3)}$ \\ $1,2,3$ Mahasaraswati Denpasar University, Indonesia
}

\begin{abstract}
This study aims to analyze the effect of obedience pressure, time budget pressure and task complexity on audit judgment with emotional intelligence as a moderating variable in BPKP Bali Province. The population of this research is auditors who work at BPKP Bali Province. The sample in this study were 68 respondents who were determined based on the saturated sampling method. The results showed that obedience pressure had no effect on audit judgment, time budget pressure and task complexity had a negative effect on audit judgment, emotional intelligence had a positive effect on audit judgment, emotional intelligence strengthened the relationship between obedience pressure and time budget pressure and emotional intelligence was unable to moderate the relationship complexity duty against audit judgment.
\end{abstract}

Keywords: Pressure of obedience, time budget pressure, task complexity, audit judgment and emotional intelligence.

\section{INTRODUCTION}

Creating good governance is a prerequisite for each government to meet the aspirations of citizens and achieve the goals and ideals of the nation and the country (Ariyantini, et al 2014) . According to (Mardiasmo,2018:149), there are 3 aspects that support the realization of good governance are: supervision, control and audit. Audit is the activity of checking the performance results in accordance with established standards. This audit is commonly referred to as a public sector audit (Ariyantini, et al 2014) In the public sector, the party carrying out the audit is the Financial and Development Supervisory Agency (BPKP). BPKP is an internal government agency, which has strategic duties and authorities in monitoring and checking financial management and state development. In carrying out the audit function, BPKP needs to be supported by the performance of its auditors. Each auditor has a certain point of view in addressing each audit that is being done, both from the method of answering and managing the data obtained related to the responsibilities and risks of audits in connection with the judgment made (Putri, 2017)

The quality of judgment shows how well an auditor performs in doing their job. Like some cases that happen in Indonesia, there are cases of Levy that occurred in ten attractions Karangasem, starting the case of occurred in 2017 involving levy officers at Tulamben tourist attraction where the tickets made and issued by the Tourism Office are not in accordance with the income in the original income of Karangasem (tribun-bali.com, 2019). In this case, the state prosecutor (Kejari) Karangasem assigned BPKP to calculate the losses from the levy case that occurred in ten attractions Karangasem, but until 2019 then has not also issued the results of losses from the case. In 2018 there was a bribery case conducted by the former General Manager of PT Jasa Marga Purbaleunyi branch, it is known that some BPK auditors were given a Harley Davidson Sportster 883 motorcycle in 2000 worth Rp. 115 million and night entertainment facilities as a service so that there are no findings of examination results with a specific purpose (PDTT) from BPK on the management of business revenues, cost control, and investment of PT Jasa Marga (Liputan6.com 2018) Furthermore, in 2019 BPKP and BPK center blamed by KPK because four years have passed RJ Lino corruption case

*Corresponding Author email address: shintadewi@unmas.ac.id 


\section{AFEBI Accounting Review (AAR) \\ Volume 6, No 01 (2021)}

occurred but never finished (Mnews.id, 2019).

There are several aspects that can influence auditors in the making of audit judgment is the pressure of obedience, for auditors in performing their duties must comply with and stick to professional ethics and auditing standards (Drupadi, and Sudana 2015). But there is not often a conflict when the auditor seeks to fulfill his professional responsibilities but on the other hand it is also required to fulfill orders from superiors or entities examined. This kind of conflict can make auditors confused in maintaining their independence (Putri, 2017).

The next aspect is the pressure of the time budget, the time constraints may arise from the limitations of the resources allocated to perform the task. This is one type of pressure that really has the potential to reduce auditor control over their field of work (Ritayani et al, 2017). According to (Putri, 2017), difficulty, time, or cost is a valid basis for auditors to negate an audit procedure when receiving less persuasive audit evidence. Proper planning, assisting auditors in working on the availability of time and resources appropriate for the implementation of audits.

The complexity of the task is an unstructured, difficult to understand and ambiguous task (Puspitasari and Utomo, 2011). According to Restuningdiah and Indriantoro (2000) stated that complexity arises from ambiguity and weak structure, both in the main tasks and other tasks. Testing the complexity of tasks in audits is also important because the tendency of the task of carrying out audits is a complex task.

Emotional intelligence is the intelligence to use emotions according to will, the skill to regulate emotions so as to give a positive influence (Suwandi 2015). According to (Swari and Ramantha, 2013), people with good emotional intelligence are able to think clearly even under pressure, act ethically, stick to principles and have an ability to excel. The absence of high emotional intelligence can help in the taking of judgment made by auditors so that in this case the variable of emotional intelligence serves as a moderation variable.

\section{LITERATURE STUDY}

\subsection{Cognitive Theory}

The cognitive theory put forward by Piaget (1976) states that looking at learning as a process that provides the function of cognition elements, especially the mind to know and understand the stimulus that comes from the outside. This theory emphasizes how the process or efforts optimize the ability of rational aspects possessed by others. According to Piaget (1976), there are three main principles of learning for humans, namely active learning (the development of elements of knowledge, abilities, and initiatives of individuals), learning through social interaction (cognitive development leads to many views), and learning through own experience. Auditor consideration depends largely on perception of a situation.

\subsection{Audit Judgment}

Audit judgment is a personal consideration or way of view of the auditor in responding to information that affects the documentation of evidence as well as decision making of the auditor's opinion on the financial statements of an entity (Putri, 2017). The judgment process depends on the continuous arrival of information, so it can affect the choice and the way the choice is made. Every step in the incremental judgment process, if information keeps coming will appear new considerations and new decisions or choices. Rochmawati (2009) explained the stages performed during the assessment judgment, namely formulating the issue, collecting relevant information, finding the best alternatives, then implementing and evaluating the results. 


\section{AUDIT JUDGMENT WITH EMOTIONAL INTELLIGENCE AS MODERATION \\ VARIABLE IN BPKP BALI}

\subsection{Pressure of Obedience}

The pressure of obedience is generally generated by the who have power. In this case the pressure of obedience is interpreted as the pressure received by the junior auditor from the senior auditor or the supervisor and the examined entity to take an action that deviates from ethical and professional standards. According to Drupadi and Sudana (2015), if an auditor is pressured by the supervisor then the audit judgment taken will be inaccurate because in producing judgment, the auditor who gets the order will tend to fulfill the wishes of the supervisor despite opposition to the professional standards of public accountants. This statement is supported by Drupadi and Sudana (2015) which states that strict pressure negatively affects audit judgment. The greater the pressure of obedience faced by an auditor, the more likely the judgment taken by the auditor will be inaccurate.

$\mathrm{H}_{1}$ : Pressure of obedience negatively affects audit judgment.

\subsection{Time Budget Pressure}

Time budget pressure is a time constraint that may arise from the limitations of resources allocated to carry out tasks. This is one type of pressure that really has the potential to decrease auditor control over the work environment (Putri, 2017). According to Ritayani, et al. (2017), increasing budgetary pressures received by auditors will make auditors conduct improper audit judgments. Auditors tend to behave defiantly by conducting audits not in accordance with established procedures and planning when facing time budget pressures, this will have an impact on the quality of the audit assessment that decreases. This statement is in line with Ritayani, et al. (2017) which showed that time budget pressures negatively affect audit judgment.

$\mathrm{H}_{2}$ : Time budget pressure negatively affects audit judgment.

\subsection{Task Complexity}

The complexity of a task is the difficulty of a task caused by limitations of capability and memory as well as the ability to integrate problems that decision makers have (Jamilah, et al. 2007). Related to auditing activities, the high complexity of this audit can cause accountants to behave dysfunctional, resulting in a decrease in audit quality. Auditors feel that the audit task they face is a complex task so that the auditor has difficulty in performing the task and cannot make a professional judgment. Results of the study Ningrum (2019) which states that the complexity of the task negatively affects the audit judgment.

$\mathrm{H}_{3}$ : Task complexity negatively affects the audit judgment.

\subsection{Emotional Intelligence}

Emotional intelligence is the intelligence to use emotions according to desire, the ability to control emotions so as to give a positive impact (Suwandi, 2015). Emotional intelligence can help build relationships toward happiness and wellbeing. In audit assignment, there are many work situations that can cause stress for an auditor, with emotional intelligence, then an auditor will be able to manage their emotions and thoughts so as not to be affected by work stress so that the audit judgment made will be free from the influences of stress or chaotic thoughts (Suwandi, 2015). According to Suwandi (2015), emotional intelligence will be very useful for an auditor in making a more precise audit judgment. When an auditor is faced with a situation of dilemma and heavy workload, auditors who have good emotional intelligence will still focus their minds so as not to be burdened by work stress, so that he can still analyze every problem, pressure from superiors and companies, time budget pressure and still be able to work with colleagues and clients when experiencing complex and unstructured tasks. 
$\mathrm{H}_{4}$ : Emotional intelligence positively affects audit judgment.

$\mathrm{H}_{5}$ : Emotional intelligence weakens the influence of the pressure of obedience to audit judgment.

$\mathrm{H}_{6}$ : Emotional intelligence weakens the influence of budgetary pressure on audit judgment.

$\mathrm{H}_{7}$ : Emotional intelligence weakens the influence of complexity of tasks on audit judgment.

\section{RESEARCH METHODS}

This research was conducted at BPKP Bali Office which is located at Jl. Tantular, Renon, Denpasar Bali. The types of data used in this study are qualitative data and quantitative data. The population in this study was 68 auditors at BPKP Bali by testing the influence of obedience pressures, time budget pressures, task complexity and emotional intelligence. The sampling method used in this study was saturated sampling. The samples in this study are all auditors who work at BPKP Bali with a total of 68 auditors. The technique used in testing this research data is moderated regression analysis (MRA) analysis technique.

\subsection{Validity Test}

Validity Test is used to measure the validity or validity of a questionnaire (Ghozali 2018: 51). Validity test results are presented in Table 1.

Table 1 Validity Test Results

\begin{tabular}{|l|l|l|l|l|}
\hline Statement & $\begin{array}{l}\text { Pearson } \\
\text { Correlation }\end{array}$ & Standar & Sig. & Information. \\
\hline Pressure of Obedience (PO) \\
\hline PO. 1 & 0,709 & 0,30 & 0,000 & Valid \\
\hline PO.2 & 0,451 & 0,30 & 0,000 & Valid \\
\hline PO.3 & 0,635 & 0,30 & 0,000 & Valid \\
\hline PO.4 & 0,730 & 0,30 & 0,000 & Valid \\
\hline PO.5 & 0,585 & 0,30 & 0,000 & Valid \\
\hline PO.6 & 0,778 & 0,30 & 0,000 & Valid \\
\hline PO.7 & 0,588 & 0,30 & 0,000 & Valid \\
\hline Time Budget Pressure (TBP) & & \\
\hline TBP.1 & 0,562 & 0,30 & 0,000 & Valid \\
\hline TBP. 2 & 0,581 & 0,30 & 0,000 & Valid \\
\hline TBP.3 & 0,656 & 0,30 & 0,000 & Valid \\
\hline TBP.4 & 0,651 & 0,30 & 0,000 & Valid \\
\hline TBP.5 & 0,501 & 0,30 & 0,000 & Valid \\
\hline TBP.6 & 0,560 & 0,30 & 0,000 & Valid \\
\hline TBP.7 & 0,466 & 0,30 & 0,000 & Valid \\
\hline TBP.8 & 0,639 & 0,30 & 0,000 & Valid \\
\hline Task Complexity (TC) & 0,511 & 0,30 & 0,000 & Valid \\
\hline TC.1 & 0,879 & 0,30 & 0,000 & Valid \\
\hline TC.2 & 0,893 & 0,30 & 0,000 & Valid \\
\hline TC.3 & 0,807 & 0,30 & 0,000 & Valid \\
\hline TC.4 & 0,745 & 0,30 & 0,000 & Valid \\
\hline TC.5 & 0,752 & 0,30 & 0,000 & Valid \\
\hline TC.6 & \multicolumn{5}{|l|}{} \\
\hline Audit Judgment (AJ) & \multicolumn{5}{|l|}{} \\
\hline
\end{tabular}




\begin{tabular}{|c|c|c|c|c|}
\hline AJ.1 & 0,841 & 0,30 & 0,000 & Valid \\
\hline AJ.2 & 0,582 & 0,30 & 0,000 & Valid \\
\hline AJ.3 & 0,582 & 0,30 & 0,000 & Valid \\
\hline AJ.4 & 0,462 & 0,30 & 0,000 & Valid \\
\hline AJ.5 & 0,377 & 0,30 & 0,000 & Valid \\
\hline AJ.6 & 0,841 & 0,30 & 0,000 & Valid \\
\hline AJ.7 & 0,634 & 0,30 & 0,000 & Valid \\
\hline \multicolumn{5}{|c|}{ Emotional Intelligence (EI) } \\
\hline EI.1 & 0,738 & 0,30 & 0,000 & Valid \\
\hline EI.2 & 0,552 & 0,30 & 0,000 & Valid \\
\hline EI.3 & 0,813 & 0,30 & 0,000 & Valid \\
\hline EI.4 & 0,895 & 0,30 & 0,000 & Valid \\
\hline EI.5 & 0,696 & 0,30 & 0,000 & Valid \\
\hline EI.6 & 0,891 & 0,30 & 0,000 & Valid \\
\hline EI.7 & 0,811 & 0,30 & 0,000 & Valid \\
\hline
\end{tabular}

Source: Data processed (2021)

Based on Table 1 the test results of the research instrument showed that all question items from the five variables studied pearson correlation value was above 0.30 so that all question items in the instrument were said to be valid.

\subsection{Reliability Test}

Reliability is a tool for measuring a questionnaire that is an indicator of variables (Ghozali, 2018:47). Question items or statements can be said to be reliable if the Cronbach alpha $(\alpha)>$ value is 0.70 . Reliability test results are presented in Table 2 .

Table 2 Reliability Test Results

\begin{tabular}{|l|l|l|l|l|}
\hline Variabel & $\begin{array}{l}\text { Number of } \\
\text { Instruments }\end{array}$ & $\begin{array}{l}\text { Cronbac } \\
\text { h's Alpha }\end{array}$ & Standard & Information \\
\hline Pressure Of Obedience (PO) & 7 & 0,735 & 0,70 & Reliabel \\
\hline Time Budget Pressure (TBP) & 8 & 0,709 & 0,70 & Reliabel \\
\hline Task Complexity (TC) & 6 & 0,856 & 0,70 & Reliabel \\
\hline Audit Judgment (AJ) & 7 & 0,732 & 0,70 & Reliabel \\
\hline Emotional Intelligence (EI) & 7 & 0,891 & 0,70 & Reliabel \\
\hline
\end{tabular}

Source: Data processed (2021)

Based on Table 2 it can be seen that the value of Cronbach's alpha of each variable has a value greater than 0.70 . This suggests that all the statements in this research questionnaire are reliable and usable.

\subsection{Descriptive Statistics}

Descriptive statistics are statistics used to analyze data by describing or describing the collected data as it is without intending to make conclusions that apply to the public or generalization (Sugiyono 2018: 206). This analysis is done by explaining the minimum, maximum, average, and standard deviation values. Descriptive statistical test results are presented in Table 3. 
Table 3 Descriptive Statistical Test Results

\begin{tabular}{|c|c|c|c|c|c|}
\hline \multicolumn{6}{|l|}{ Descriptive Statistics } \\
\hline & $\mathrm{N}$ & Minimum & Maximum & Mean & $\begin{array}{l}\text { Std. } \\
\text { Deviation }\end{array}$ \\
\hline $\mathrm{PO}$ & 68 & 25.00 & 35.00 & 29.7906 & 2.63144 \\
\hline TBP & 68 & 26.00 & 39.00 & 35.1176 & 2.69621 \\
\hline $\mathrm{TC}$ & 68 & 18.00 & 30.00 & 24.6618 & 3.05478 \\
\hline AJ & 68 & 25.00 & 35.00 & 27.8382 & 1.85770 \\
\hline EI & 68 & 21.00 & 32.00 & 26.0588 & 2.96186 \\
\hline Valid N (listwise) & 68 & & & & \\
\hline
\end{tabular}

Source: Data processed (2021)

Based on the results of descriptive statistical tests in Table 3 can be described as follows:

The Pressure of Obedience (PO) has a minimum value of 25.00 and a maximum value of 35.00 with a mean value of 27.8382 and a standard deviation value of 2.63144 . This means that there is a deviation of variables to the average value of 2.63144. The Time Budget Pressure Variable (TBP) has a minimum value of 26.00 and a maximum value of 39.00 with a mean value of 35.1176 and a standard deviation of 2.69621. This means that there is a deviation of variables to the average value of 2.69621. Task Complexity Variable (TC) has a minimum value of 18.00 and a maximum value of 30.00 with a mean value of 24.6618 and a standard deviation value of 3.05478. This means that there is a variable deviation to the average value of 3.05478. Variable Audit Judgment (AJ) has a minimum value of 25.00 and a maximum value of 35.00 with a mean value of 27.8382 and a standard deviation value of 1.85770. This means that there is a deviation of variables to the average value of 1.85770 . The Emotional Intelligence Variable (EI) has a minimum value of 21.00 and a maximum value of 32.00 with a mean value of 26.0588 and a standard deviation value of 2.96186 . This means that there is a deviation of variables to the average value of 2.96186 .

\subsection{Moderated Regression Analysis (MRA)}

The results of moderated regression analysis (MRA) test are presented in Table 4 Table 4 Moderated Regression Analysis (MRA)

\begin{tabular}{|c|c|c|c|c|c|c|c|c|}
\hline \multicolumn{9}{|c|}{ Coefficients $^{\mathrm{a}}$} \\
\hline \multirow{2}{*}{\multicolumn{2}{|c|}{ Model }} & \multicolumn{2}{|c|}{$\begin{array}{c}\text { Unstandardized } \\
\text { Coefficients } \\
\end{array}$} & \multirow{2}{*}{$\begin{array}{c}\begin{array}{c}\text { Standardized } \\
\text { Coefficients }\end{array} \\
\text { Beta } \\
\end{array}$} & \multirow{2}{*}{$\tau$} & \multirow[b]{2}{*}{ Sig. } & \multicolumn{2}{|c|}{$\begin{array}{c}\text { Collinearity } \\
\text { Statistics }\end{array}$} \\
\hline & & B & Std. Error & & & & Tolerance & VIF \\
\hline \multirow[t]{8}{*}{1} & Constant & 41.053 & 3.142 & & 13.066 & .000 & & \\
\hline & $\mathrm{PO}$ & .002 & .003 & .042 & .536 & .594 & .438 & 2.282 \\
\hline & TBP & -.354 & .050 & -.514 & -7.068 & .000 & .124 & 8.070 \\
\hline & $\mathrm{TC}$ & -.177 & .033 & -.468 & -5.538 & .000 & .348 & 2.877 \\
\hline & EI & .119 & .032 & .299 & 3.702 & .000 & .406 & 2.462 \\
\hline & PO*EI & .010 & .003 & .197 & 3.341 & .001 & .149 & 6.714 \\
\hline & TBP*EI & .007 & .003 & .178 & 2.051 & .045 & .353 & 2.830 \\
\hline & TC*EI & .003 & .003 & .081 & .952 & .345 & .369 & 2.712 \\
\hline
\end{tabular}

a. Dependent Variable: AJ

Source: Data processed (2021)

Based on the results of the analysis in Table 4 produced the following equations: 


$$
\begin{aligned}
\mathrm{AJ}= & 41.053+0,002(\text { PO })-0,354(\text { TBP })-0,177(\text { TC })+0,119(\text { EI })+0,010(\text { PO*EI })+ \\
& 0,007(\text { TBP*EI })+0,003(\text { TC* EI })
\end{aligned}
$$

\subsection{Classic Assumption Test}

Normality Test and Multicolinearity Test

Table 5 Normality Test Results

\begin{tabular}{|l|l|l|}
\hline \multicolumn{2}{|c|}{ One-Sample Kolmogorov-Smirnov Test } \\
\hline \multirow{2}{*}{$\mathrm{N}$} & & $\begin{array}{l}\text { Unstandardized } \\
\text { Residual }\end{array}$ \\
\hline \multirow{2}{*}{ Normal Parameters ${ }^{\mathrm{a}, \mathrm{b}}$} & Mean & 68 \\
\cline { 2 - 3 } & Std. Deviation & .0000000 \\
\hline \multirow{2}{*}{$\begin{array}{l}\text { Most Extreme } \\
\text { Differences }\end{array}$} & Absolute & .179 \\
\cline { 2 - 3 } & Positive & .129 \\
\cline { 2 - 3 } & Negative & -.179 \\
\hline Kolmogorov-Smirnov Z & .887 \\
\hline Asymp. Sig. (2-tailed) & .410 \\
\hline \multicolumn{2}{|l|}{ a. Test distribution is Normal. } \\
\hline b. Calculated from data. \\
\hline
\end{tabular}

Source: Data processed (2021)

Based on Table 5 which indicates that the value is Asymp. Sig. (2-tailed) of 0.410 which is greater than 0.05 , it can be concluded that the data used in this study is normally distributed. Based on Table 4 which shows that the tolerance value of all independent variables $>0.10$ and VIF values of all independent variables $<10$ can be concluded that there are no symptoms of multicollinearity between variables in the regression model.

Heteroskedastisitas Test

\begin{tabular}{|c|c|c|c|c|c|c|}
\hline \multicolumn{7}{|c|}{ Coefficients $^{\mathrm{a}}$} \\
\hline & \multirow[b]{2}{*}{ Model } & \multicolumn{2}{|c|}{$\begin{array}{l}\text { Unstandardized } \\
\text { Coefficients }\end{array}$} & \multirow{2}{*}{\begin{tabular}{|c|} 
Standardized \\
Coefficients \\
Beta \\
\end{tabular}} & \multirow[b]{2}{*}{$\mathrm{t}$} & \multirow[b]{2}{*}{ Sig. } \\
\hline & & $\mathrm{B}$ & Std. Error & & & \\
\hline \multirow[t]{8}{*}{1} & (Constant) & 4.368 & 4.880 & & .895 & .374 \\
\hline & $\mathrm{PO}$ & .000 & .005 & -.013 & -.071 & .944 \\
\hline & TBP & -.155 & .078 & -.262 & -1.480 & .144 \\
\hline & $\mathrm{TC}$ & -.037 & .051 & -.153 & -.722 & .473 \\
\hline & EI & -.071 & .050 & -.281 & -1.430 & .158 \\
\hline & PO*EI & .002 & .005 & .074 & .518 & .607 \\
\hline & TBP*EI & .000 & .005 & .020 & .094 & .925 \\
\hline & TC*EI & .002 & .005 & .084 & .409 & .684 \\
\hline
\end{tabular}

Table 6 Heteroskedastisitas Test Results

Source: Data processed (2021)

Based on Table 6 which shows that the significance value of all independent variables $>$ 0.05. This suggests that the regression model does not occur heteroskedasticities. 


\section{RESULTS AND DISCUSSION}

\section{Effect of Compliance Pressure on Audit Judgment}

Based on the results of moderated regression analysis (MRA) tests that have been conducted obtained results that the pressure variable adherence has a regression coefficient value of 0.002 which gives a positive direction and a calculated $t$ value of 0.536 with a significance value of 0.594 greater than 0.05 . This indicates that the pressure of obedience has no effect on the audit judgment which means $\mathrm{H}_{1}$ is rejected. Pressure is generally generated by individual which has powers that can affect one's behavior with the commands given. In this case the pressure of obedience is interpreted as the pressure received by auditors from superiors and entities being examined to take actions that deviate from their professional standards the results of this study are in line with the research of (Putri, 2018) and Nirmala, \& Latrini (2017) which states that the pressure of obedience has no effect on the quality of the audit judgment

\section{Effect of Time Budget Pressure on Audit Judgment}

Based on the results of moderated regression analysis (MRA) tests that have been conducted obtained the results that the time budget pressure variable has a regression coefficient value of -0.354 which gives a negative direction and a calculated $t$ value of $-7,068$ with a significance value of 0.000 smaller than 0.05 . This suggests that time budgetary pressures negatively affect audit judgment which means $\mathrm{H}_{2}$ is accepted. Auditors often work in time constraints that can affect their performance to obtain quality audit results. According to Ritayani, et al. (2017), in performing audit tasks, auditors are required to complete their obligations in accordance with the budget received, but the level of budget reaching the auditor's time in carrying out audit tasks tends to be low because of the high tightness of the time budget received by auditors when performing audit tasks. The budgeted time for an auditor to complete his task is very little, not worth the task he has to deal with. Auditors are likely to behave defiantly by carrying out audits not according to established procedures and planning when facing time budget pressures. The results of this study are in line with the research of Ritayani, et al. (2017) and Nirmala and Latrini (2017) which showed that budgetary pressures negatively affect the quality of audit judgment.

\section{The Effect of Task Complexity on Audit Judgment}

Based on the results of moderated regression analysis (MRA) tests that have been conducted obtained results that the task complexity variable has a regression coefficient value of -0.177 which gives a negative direction and a calculated $t$ value of $-5,358$ with a significance value of 0.000 smaller than 0.05 . This suggests that the complexity of the task negatively affects the audit judgment which means $\mathrm{H}_{3}$ is accepted. The complexity of a task is an unstructured, ambiguous and difficult task to understand. According to Ariyantini, et al. (2014),complexity arises from ambiguity and weak structure, both in major tasks and other tasks. Confusing tasks, irrelevant and unstructured information, unconstructed alternatives will make it difficult for auditors to perform audit tasks and cannot make professional judgments. As a result the resulting judgment does not match the existing evidence (Ningrum, 2019). The results of this study are in line with the research of Ariyantini, et al. (2014) and Ningrum (2019) which stated that the complexity of the task negatively affects the audit judgment.

\section{The Effect of Emotional Intelligence on Audit Judgment}

Based on the results of moderated regression analysis (MRA) tests that have been conducted obtained results that emotional intelligence variables have a coefficient of 


\section{AUDIT JUDGMENT WITH EMOTIONAL INTELLIGENCE AS MODERATION}

VARIABLE IN BPKP BALI

regression value of 0.119 that gives a positive direction and a calculated t value of 3,702 with a significance value of 0.000 smaller than 0.05 . This suggests that emotional intelligence positively influenced the audit judgment which meant $\mathrm{H}_{4}$ was accepted. In the audit, there are many work situations that can cause stress for an auditor, with the presence of emotional intelligence, then an auditor will be able to manage their emotions and thoughts so as not to be affected by work stress so that the audit judgment made will be free from the effects of stress or chaotic thoughts. The results of this study are in line with Suwandi (2015) and Swari and Ramantha (2013) which stated that emotional intelligence positively affects the consideration of giving auditors opinions.

\section{The Effect of Emotional Intelligence on Relationships Pressures Obedience to Audit Judgment}

Based on the results of moderated regression analysis (MRA) tests that have been conducted obtained results that the interaction of pressure variables obedience with emotional intelligence has a coefficient of regression value of 0.010 and a calculated $t$ value of 3,341 with a significance value of 0.001 smaller than 0.05 . This suggests that emotional intelligence amplifies the influence of the pressure of obedience to the audit judgment which means $\mathrm{H}_{5}$ is rejected. Junior auditors with emotional intelligence are likely to focus their focus on the orders of supervisors and entities examined. This suggests that junior auditors do not have the courage to defy the orders of the supervisors and entities examined even if the instructions deviate from the auditor's professional standards. The higher the auditor's emotional intelligence, the higher the pressure of obedience received by the auditor so as to improve the quality of audit judgment. The results of this study are in line with Rifki (2016) which states that emotional intelligence moderates variable role conflicts against auditor performance. This suggests that emotional intelligence can help auditors when faced with the pressures or demands exerted by the roles that the auditor has in achieving their performance thereby improving overall performance.

\section{The Effect of Emotional Intelligence on The Relationship of Time Budget Pressures on Audit Judgment}

Based on the results of moderated regression analysis (MRA) tests that have been conducted obtained the results that the interaction of variable time budget pressure with emotional intelligence has a coefficient of regression value of 0.007 and a calculated $t$ value of 2.051 with a significance value of 0.045 smaller than 0.05 . This suggests that emotional intelligence amplifies the effect of budgetary pressures on audit judgment which means $\mathrm{H}_{6}$ is rejected. Often auditors who are faced with a predetermined time limit will be motivated to make careful planning before performing audit tasks. With emotional intelligence that moderates the pressures of the time budget can help auditors to be more careful in making audit planning so that auditors are able to provide proper judgment on the information and evidence available. The results of this study are in line with the research of Wiryathi, et al. (2014) which states that emotional intelligence moderates the influence of role conflict, role ambiguity, and role overload on burnout experienced by auditors, this shows that auditors with high emotional intelligence will be able to adapt and manage emotions better to deal with stress due to role conflict, role ambiguity, and role overload experienced by auditors.

\section{The Effect of Emotional Intelligence on Task Complexity Relationships on Audit Judgment}

Based on the results of moderated regression analysis (MRA) tests that have been conducted obtained the results that the interaction of complexity variables tasks with emotional intelligence has a coefficient of regression value of 0.003 and a calculated $t$ value 


\section{AFEBI Accounting Review (AAR) \\ Volume 6, No 01 (2021)}

of 0.952 with a significance value of 0.345 greater than 0.05 . This suggests that emotional intelligence is incapable of moderating the complexity of the task to audit judgment which means $\mathrm{H}_{7}$ is rejected. Auditors who have emotional intelligence when faced with unstructured tasks have no effect on the judgment made. To be able to complete complex tasks, auditors need not only good emotional intelligence but other necessary factors such as education, knowledge, experience and auditor expertise to assist auditors in analyzing difficult and unstructured tasks. The results of this study are in line with Dahniar and Arfah (2019) which stated that emotional intelligence does not moderate variable role conflict to auditor performance. This suggests that emotional intelligence cannot help auditors when faced with pressures or demands given in achieving their performance, thus lowering overall performance.

\section{CONCLUSIONS}

Based on the results of the research that has been done, it can be concluded that: The pressure of obedience has no effect on the audit judgment. Budgetary pressures on time and the effectiveness of tasks negatively affect audit judgment. Emotional intelligence has a positive effect on audit judgment. Emotional intelligence reinforces the pressure relationship of obedience to audit judgment. Emotional intelligence reinforces the relationship of budgetary pressures to audit judgment. Emotional intelligence is incapable of moderating the complexity relationship of tasks to audit judgment.

Based on the conclusions and limitations in this study, it can be submitted several suggestions, namely: research then expected to use google form at the time of the study to facilitate respondents when filling out questionnaires and add with interview methods to get direct answers from respondents so that respondents and researchers can equate perceptions directly about factors that affect the audit judgment.

The Covid-19 pandemic caused the government to implement a work from home system. This causes the intensity of the respondent's presence to the research site is reduced so that the process of collecting the results of answers from respondents takes a long time because questionnaires can be filled out when respondents are present to the research site.

\section{REFERENCE}

Ariyantini, Kadek Evi; Sujana, Edy; Darmawan, Nyoman Ari Surya. 2014. "Pengaruh Pengalaman Auditor, Tekanan Ketaatan Dan Kompleksitas Tugas Terhadap Audit Judgment (Studi Empiris Pada BPKP Perwakilan Provinsi Bali).” JIMAT (Jurnal Ilmiah Mahasiswa Akuntansi S1) 2(1). doi: 10.23887/jimat.v2i1.2888.

Dahniar Aurora ; Eka Ariaty Arfah. 2019. "Moderasi Kecerdasan Emosional : Pengaruh Role Stress Terhadap Kinerja Auditor." Jurnal Ilmiah Akuntansi 2(2):41-65.

Drupadi, Made Julia; Sudana, I. Putu. 2015. "Pengaruh Keahlian Auditor, Tekanan Ketaatan

Dan Independensi Pada Audit Judgment." E-Jurnal Akuntansi Universitas Udayana 12(3):623-55.

Ghozali, Imam. 2018. Aplikasi Analisis Multivariate Dengan Program IBM SPSS 25,. Sembilan. Semarang: Undip.

Jamilah, Siti, Zaenal Fanani, and Grahitaarin Chandr. 2007. "Pengaruh Gender, Tekanan Ketaatan, Dan Kompleksitas Tugas Terhadap Audit Judgment." Simposium Nasional Akuntansi 10 1-30.

Liputan6.com. 2018. "Suap Harley Davidson, Eks GM Jasa Marga Divonis 1,5 Tahun Penjara." Https://Www.Liputan6.Com/News/Read/3355533/Suap-Harley-Davidson-EksGm-Jasa-Marga-Divonis-15-Tahun-Penjara.

Mardiasmo. 2018. Akuntansi Sektor Publik. Bandung: ANDI. 


\section{AUDIT JUDGMENT WITH EMOTIONAL INTELLIGENCE AS MODERATION \\ VARIABLE IN BPKP BALI}

Mnews.id. 2019. "Empat Tahun Kasus Korupsi RJ Lino Gak Kunjung Selesai, KPK Salahkan BPKP Dan BPK." Https://Www.Minews.Id/News/Empat-Tahun-Kasus-Korupsi-Rj-LinoGak-Kunjung-Selesai-Kpk-Salahkan-Bpkp-Dan-Bpk.

Wiryathi Ni Made; Ni Ketut Rasmini; Made Gede Wirakusuma. 2014. "Pengaruh Role Stressors Pada Burnout Auditor Dengan Kecerdasan Emosional Sebagai Variabel Pemoderasi." E-Jurnal Ekonomi Dan Bisnis Universitas Udayana 03(05):227-44.

Ningrum, Selfi Sagita Mandata. 2019. "Pengaruh Gender, Tekanan Ketaatan, Kompleksitas Tugas Dan Pengalaman Audit Terhadap Audit Judgment (Studi Kasus Pada Kantor Akuntan Publik)." Skripsi Universitas Mahasaraswati Denpasar.

Nirmala, M. R. V., \& Latrini, M. Y. 2017. "Pengaruh Keahlian, Tekanan Ketaatan, Tekanan Waktu Terhadap Kualitas Audit Judgment Dengan Kompleksitas Tugas Sebagai

Pemoderasi." E-Jurnal Akuntansi Universitas Udayana 19(1),:683-711.

Piaget, Jean. 1976. A Reader in Developmental Psychology.

Puspitasari, Rahmi Ayu. 2011. "Analisis Pengaruh Gender, Tekanan Ketaatan, Kompleksitas Tugas Dan Pengalaman Terhadap Kinerja Auditor Dalam Pembuatan Audit Judgmen." Skripsi Universitas Diponegoro Semarang.

Putri, Andini Rahmatika. 2017. "Pengaruh Tekanan Anggaran Waktu, Kompleksitas Tugas, Pengetahuan Auditor, Dan Pengalaman Auditor Terhadap Audit Judgment (Studi Kasus Pada KAP Di Pekanbaru, Batam, Dan Padang)." JOM Fekon 4(1):1282-94.

Putri, Ni Wayan Luh Batuan Mahatmi. 2017. "Pengaruh Gender, Keahlian Auditor Dan Tekanan Ketaatan Terhadap Audit Judgment Dengan Kompleksitas Tugas Sebagai Variabel Moderasi Pada BPKP Provinsi Bali." Skripsi Universitas Hindu Indonesia Denpasar.

Putri, Winda Eka. 2018. "Pengaruh Tekanan Ketaatan, Pengalama Audit, Kompleksitas Tugas Dan Independensi Terhadap Audit Judgment." 1-19.

Restuningdiah, Nurika \& Indriantoro, Nur. 2000. "Pengaruh Partisipasi Terhadap Kepuasaan Pemakai Dalam Pengembangan Sistem Informasi Dengan Kompleksitas Tugas, Kompleksitas System, Dan Pengaruh Pemakai Sebagai Moderating Variable.” Jurnal Riset Akuntansi Indonesia 3(2):119-33.

Rifki Patria. 2016. "Pengaruh Konflik Peran Dan Ambiguitas Peran Terhadap Kinerja Auditor Dengan Kecerdasan Emosional Sebagai Variabel Moderasi (Studi Empiris Pada KAP Di Pekanbaru Padang Dan Batam)." JOM Fekon 3(1):881-95.

Ritayani, Desak Nyoman, Edy Sujana, and I. Gusti Ayu Purnamawati. 2017. "Pengaruh Self Efficacy Dan Tekanan Anggaran Waktu Terhadap Audit Judgment Dengan Profesionalisme Sebagai Variabel Moderasi (Studi Empiris Pada Kantor Akuntan Publik

Di Provinsi Bali)." E-Journal S1 Ak Universitas Pendidikan Ganesha Jurusan Akuntansi Program S1 8(2):1-12.

Rochmawati, Devi Vivi. 2009. "Pengaruh Pemahaman Kode Etik Profesi Akuntan Dan Pengalaman Audit Terhadap Auditor Judgment." Thesis Magister Sains Akuntansi

Universitas Diponegoro Semarang.

Sugiyono. 2018. Metode Penelitian Kuantitatif. Bandung: Alfabeta.

Suwandi. 2015. "Pengaruh Self Efficacy, Kecerdasan Emosional, Tekanan Ketaatan Dan

Kompleksitas Tugas Terhadap Audit Judgment Auditor (Studi Empiris Pada KAP Di

Pekan Baru, Padang Dan Batam)." JOM Fekon 2(1):1-15.

Swari, I. P. C. M., \& Ramantha, I. W. 2013. "Pengaruh Independensi Dan Tiga Kecerdasan

Terhadap Pertimbangan Pemberian Opini Auditor.” E-Jurnal Akuntansi 4(3),:489-508.

tribun-bali.com. 2019. "BPKP Belum Keluarkan Hasil Kerugian Kasus Pungutan Retribusi Di Sepuluh Objek Wisata Karangasem.” Https://Bali.Tribunnews.Com/2019/07/13/Bpkp-Belum-Keluarkan-Hasil-Kerugian- 
AFEBI Accounting Review (AAR)

Volume 6, No 01 (2021)

Kasus-Pungutan-Retribusi-Di-Sepuluh-Objek-Wisata-Karangasem. 